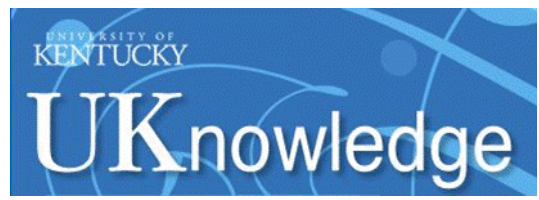

University of Kentucky

UKnowledge

Power and Energy Institute of Kentucky Faculty Publications

$11-2017$

\title{
Multi-MW Solar PV Pumping System with Capacity Modulation and Battery Voltage Support
}

Oluwaseun M. Akeyo

University of Kentucky, ochichikeyo@gmail.com

Vandana Rallabandi

University of Kentucky, vandana.rallabandi@uky.edu

Dan M. Ionel

University of Kentucky, dan.ionel@uky.edu

Follow this and additional works at: https://uknowledge.uky.edu/peik_facpub

Part of the Power and Energy Commons

Right click to open a feedback form in a new tab to let us know how this document benefits you.

\section{Repository Citation}

Akeyo, Oluwaseun M.; Rallabandi, Vandana; and Ionel, Dan M., "Multi-MW Solar PV Pumping System with Capacity Modulation and Battery Voltage Support" (2017). Power and Energy Institute of Kentucky Faculty Publications. 41.

https://uknowledge.uky.edu/peik_facpub/41

This Conference Proceeding is brought to you for free and open access by the Power and Energy Institute of Kentucky at UKnowledge. It has been accepted for inclusion in Power and Energy Institute of Kentucky Faculty Publications by an authorized administrator of UKnowledge. For more information, please contact UKnowledge@lsv.uky.edu. 


\title{
Multi-MW Solar PV Pumping System with Capacity Modulation and Battery Voltage Support
}

\author{
Digital Object Identifier (DOI) \\ https://doi.org/10.1109/ICRERA.2017.8191097
}

\section{Notes/Citation Information}

Published in 2017 IEEE 6th International Conference on Renewable Energy Research and Applications (ICRERA).

(C) 2017 IEEE Copyright Notice. "Personal use of this material is permitted. Permission from IEEE must be obtained for all other uses, in any current or future media, including reprinting/republishing this material for advertising or promotional purposes, creating new collective works, for resale or redistribution to servers or lists, or reuse of any copyrighted component of this work in other works."

The document available for download is the authors' manuscript version that is accepted for publication. The final published version is copyrighted by IEEE and will be available as: O. M. Akeyo, V. Rallabandi and D. M. Ionel, "Multi-MW solar PV pumping system with capacity modulation and battery voltage support," 2017 IEEE 6th International Conference on Renewable Energy Research and Applications (ICRERA), San Diego,CA, 2017, pp. 423-428. doi: 10.1109/ICRERA.2017.8191097. 


\title{
Multi-MW Solar PV Pumping System with Capacity Modulation and Battery Voltage Support
}

\author{
Oluwaseun M. Akeyo, Vandana Rallabandi and Dan M. Ionel \\ Department of Electrical and Computer Engineering, University of Kentucky, Lexington, KY \\ m.akeyo@uky.edu,vandana.rallabandi@uky.edu,dan.ionel@uky.edu
}

\begin{abstract}
Solar photovoltaic (PV) renewable energy systems are undergoing major technological developments and largescale field deployment and electric grid integration. This paper proposes a method of expanding the capacity of an existing irrigation farm with additional pumps powered by solar PV. The system includes PV arrays and battery energy storage connected to a common dc bus, which energizes an array of variable speed inverter driven pumps. Capacity modulation is achieved by energizing an optimal number of pumps required in order to meet a particular load demand with minimum supply energy. A grid connection to the dc bus of the power electronic system is established via a bidirectional converter, such that active and reactive power demands can be both serviced. The controls and the steady-state and transient performance of the system are implemented and simulated with the PSCAD ${ }^{T M} /$ EMTDC $^{T M}$ software.
\end{abstract}

Keywords - Renewable energy, photovoltaics, PV, PV power system, variable speed pump, irrigation farm, capacity modulation, energy storage, battery, dc bus voltage support, $\mathrm{PSCAD}^{T M} / \mathrm{EMTDC}^{T M}$.

\section{INTRODUCTION}

Pumping systems are employed for fluid distribution in both large-scale and small-scale farm irrigation establishments. Companies including World Water \& Solar Technologies Corp. have recently invested in the development of such multiMW photovoltaic (PV) installations. The renewable energy generated locally reduces the electric load requirements for the power grid. Since the amount of water required by agricultural crops varies depending on the season of the year, where summer sees the largest requirement, irrigation pumping systems are rarely operated at full capacity making them require a control method that ensures effective power supply for all load requirements.

Recent work on the topic of solar photovoltaics includes maximum power point tracking (MPPT) techniques [1-7] and applications in pumping [8-12]. Some authors focus on battery energy storage system (BESS) models and applications in solar PV power [13-15], while others discuss effective means of controlling converters for connected pumps $[16,17]$.

This paper concentrates on the use of energy from solar PV for expanding the capacity of a fixed speed multi-MW grid connected irrigation pumping farm. The system proposed to be used for this purpose includes multiple variable speed permanent magnet motor driven pumps connected through individual inverters to a dc bus powered from an array of PV panels. A buck converter is employed for MPPT, and the BESS is also connected to the dc bus through a buck-boost converter. Capacity modulation is achieved by selecting and operating the optimal combination of fixed and variable speed pumps in order to meet a particular load for the given configuration of the irrigation channels. In such a combination, it is expected that some of the variable speed pumps may operate at partial load.

The PV array serves as the primary source of power for the pumps, while the BESS is used in order to regulate the DC link voltage and thus balance the power differences between the pump demands and PV input. In case of unavailability of the battery due to state of charge (SOC) constraints, a connection to the grid is established via a bi-directional DCAC converter. In addition, reactive power transfer to the grid is possible under operating conditions, which otherwise lead to partial load operation of the grid side converter.

Section II describes the configuration of the battery intergated PV based irrigation system, its operating modes and sub-components, while the ratings of the system and control strategies employed are dealt with in Section III. Simulation results for different operating conditions using $\mathrm{PSCAD}^{T M} / \mathrm{EMTDC}^{T M}$ are presented in Section IV, and the paper concludes in Section V.

\section{System CONFIGURATION}

The proposed system encompasses fixed speed pumps powered by grid connected induction motors (Fig. 1). Capacity expansion is achieved by the addition of variable speed pumps capable of being energized by a combination of the PV array, BESS, and the grid. The pumping system draws power from the sources depending on the availability of solar PV, and three modes of operation may be identified as below:

Mode 1: When the PV array is producing the exact amount of power required to energize the connected pumps at required speeds, the BESS and the grid are isolated from the DC link

Mode 2: When there is a power imbalance between the PV and the connected pumps, the system BESS charges or discharges to ensure operation of the PV at MPPT condition and pumps are operated at the required load

Mode 3: When BESS is unavailable to regulate power imbalance between PV and pumps due to SOC constraints, grid connection is established. 


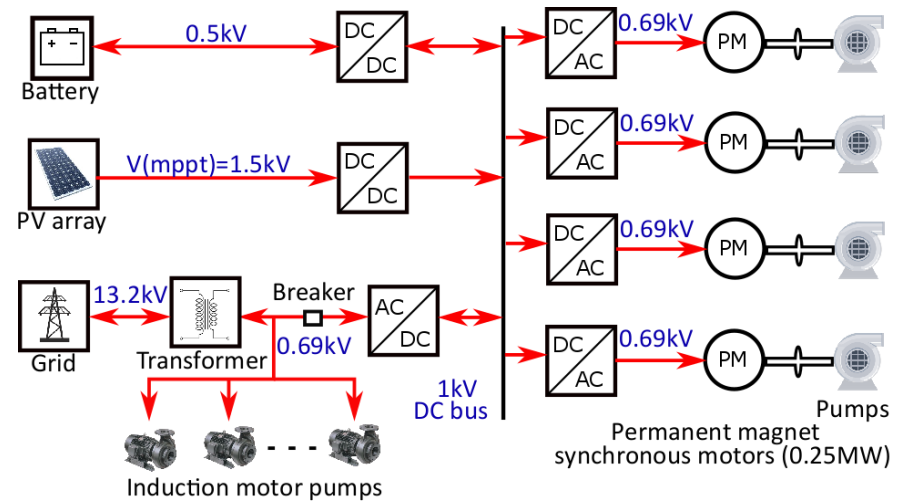

Fig. 1. Schematic overview for the expansion of an existing grid-connected irrigation pumping system with the addition of solar PV, battery, and PMSM inverter driven pumps for capacity modulation.

It is worth mentioning that the grid side inverter can be used during modes 1 and 2 , which require it to interface a small amount of active power, to also supply reactive power to the grid. The reactive power capability of the inverter is,

$$
Q=\sqrt{S^{2}-P^{2}}
$$

Where, $\mathrm{Q}$ is the reactive power that can be supplied, $\mathrm{P}$, the active power being supplied and $S$, the VA rating of the inverter. When the active power handled by the inverter is smaller than its VA rating, reactive power can be supplied. Another noteworthy operating mode is use of the battery for grid frequency regulation, when the system is in its operating mode 1 .

\section{A. PV Array}

The PV cell model incorporated in $\mathrm{PSCAD}^{T M} / \mathrm{EMTDC}^{T M}$ is based on the Norton equivalent electrical circuit, which consists of a current source connected in parallel to a diode with output through shunt and series resistances. The output current $(i)$ of the PV array is given as,

$$
i=i_{g}-i_{o}\left[e^{\left(\frac{V+i R_{s r}}{n \mathrm{~K} T_{c} / q}\right)}-1\right]-\left(\frac{V+i R_{s r}}{R_{s h}}\right),
$$

where, $i_{g}$ represents the component of cell current due to photons; $i_{o}$, the saturation current; $\mathrm{K}$, the Boltzmann constant $(\mathrm{K}$ $\left.=1.3810^{-23} \mathrm{j} / K\right) ; q$, the electron charge $\left(\mathrm{q}=1.6 \times 10^{-19} \mathrm{C}\right)$; $\mathrm{V}$, the output voltage; $T_{c}$, the cell temperature; $R_{s h}$, the shunt resistance and $R_{s r}$, the series resistance.

In (2), the photo-current $i_{g}$ depends on the amount of solar irradiance falling on the PV cell and cell temperature. The photo-current relationship with solar irradiance $(G)$ and cell temperature $\left(T_{c}\right)$ is given as,

$$
i_{g}=i_{s c R} \frac{G}{G_{R}}\left[1+\alpha_{T}\left(T_{c}-T_{c R}\right)\right],
$$

where, $i_{s c R}$ is the short circuit current at the reference solar radiation $G_{R}$ and the reference cell temperature $T_{c R} \cdot \alpha_{T}$ represents the temperature coefficient of the photo-current,

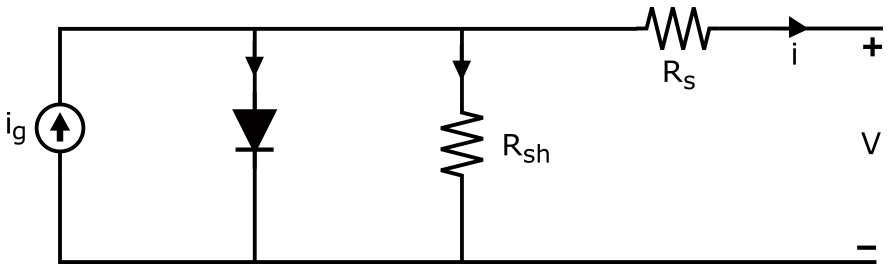

Fig. 2. Solar cell equivalent electrical circuit.

TABLE I

PV CELL AND MODULE SPECIFICATIONS

\begin{tabular}{cc} 
Parameters & Value \\
\hline Cell open circuit voltage(V) & 1.17 \\
Cell short circuit current $(\mathrm{A})$ & 4.01 \\
Cell saturation current $(\mathrm{kA})$ & $1 \mathrm{e}-12$ \\
Temperature coefficient of $i_{g}$ & 0.001 \\
Series resistance per cell $(\Omega)$ & 0.02 \\
Shunt resistance per cell $(\Omega)$ & 1000 \\
Module open circuit voltage(V) & 46.75 \\
Module short circuit current(A) & 9.02 \\
Voltage at MPP $(\mathrm{V})$ & 37.40 \\
Current at MPP $(\mathrm{A})$ & 8.50 \\
Maximum power(W) & 316.50 \\
\hline
\end{tabular}

which is usually $0.0017 \mathrm{~A} / \mathrm{K}$ for silicon solar cells. At standard test conditions (STC) the reference irradiance is given as $1000 \mathrm{~W} / \mathrm{m}^{2}$ at $25^{\circ} \mathrm{C}$ temperature. Another standard test condition is the photovoltaic for utility scale application test condition (PTC) where the reference irradiance is given as $1000 \mathrm{~W} / \mathrm{m}^{2}$ at $20^{\circ} \mathrm{C}$ temperature.

The saturation current, $i_{o}$ in (2) also known as the "darkcurrent" is a function of the cell temperature and the relationship is given by,

$$
i_{o}=i_{o R}\left(\frac{T_{c}^{3}}{T_{c R}^{3}}\right) \exp \left[\left(\frac{1}{T_{c R}}-\frac{1}{T_{c}}\right) \frac{q e_{g}}{n k}\right] .
$$

Where, $i_{O R}$ is the saturation current at the reference temperature, $e_{g}$ is the band gap energy of the solar cell material and $n$ is the diode ideal factor, typically 1.3 for silicon solar cells.

In order to meet power electronics conditioning requirements, PV modules are typically connected in series. In the system under study, the PV array is made up of $40 \mathrm{PV}$ modules connected in series and 80 module strings in parallel. Each PV module is developed based on manufacturers' data to have an open circuit voltage of $46.75 \mathrm{~V}$ and short circuit current of $9.02 \mathrm{~A}$. At $1000 \mathrm{~W} / \mathrm{m}^{2}$ solar irradiance and $25^{\circ} \mathrm{C}$ cell temperature the PV cell and module specifications are given in Table I.

\section{B. BESS}

In this design, the BESS is used to correct the power imbalance between the PV and the connected pumps as well as maintain the dc link voltage at reference value. When the amount of power required by the connected pumps is above the power from PV array, the inverter control reaches an unstable condition if BESS and grid are absent, since the commanded value of the torque producing motor current i.e. the q-axis 
reference current component $\left(i_{q}^{*}\right)$ is made to increase by the speed controller, in some cases of imbalance till the dc bus voltage falls to zero. With the presence of the BESS, the dc bus voltage can be maintained at the reference value of $1 \mathrm{kV}$ by supplying either the power deficit or drawing excess power from the PV via its DC-DC converter.

For this study, a basic model was employed for the output voltage of the battery. The output voltage of the battery model used in PSCAD is described as,

$$
E=E_{0}-K \cdot \frac{1}{S O C}+A \cdot e^{-B \cdot Q(1-S O C)} .
$$

where, $E$ is no-load voltage, $E_{0}$ is battery constant voltage, $K$ is polarization voltage, $Q$ is battery capacity, $A$ is exponential zone amplitude, $B$ is exponential zone time constant inverse and $S O C$ is the battery state of charge. This model neglects factors such as temperature, self-discharge, charge and discharge history, which may be considered based on the specific published work of other researches [18, 19].

\section{Pump System}

In this design, the induction motor pumps directly connected to the grid represent the existing pumping system used to meet the base load while the PMSM driven pumps with variable speed control, energized by the PV system are the pumps used for expanding the capacity of the irrigation farm. Each PMSM is rated for $0.25 \mathrm{MW}, 0.69 \mathrm{kV}$ at $60 \mathrm{~Hz}$ and modeled such that the per unit load torque is the square of the per unit operating speed so it represents a pump. The voltage equations for the main stator windings of the machine in the $\mathrm{dq} 0$ reference frame is given as follows,

$$
\begin{gathered}
\frac{d}{d t} i_{d}=\frac{1}{L_{d}} v_{d}-\frac{R}{L_{d}} i_{d}+\frac{L_{q}}{L_{d}} p \omega_{m} i_{q}, \\
\frac{d}{d t} i_{q}=\frac{1}{L_{q}} v_{q}-\frac{R}{L_{q}} i_{q}-\frac{L_{d}}{L_{q}} p \omega_{m} i_{d}-\frac{\lambda p \omega_{m}}{L_{q}}, \\
T_{e}=\frac{3}{2} p\left[\lambda i_{q}+\left(L_{d}-L_{q}\right) i_{d} i_{q}\right] .
\end{gathered}
$$

where $i_{d}$ and $i_{q}$ represent the $q$ and $d$ axis currents, $L_{q}$ and $L_{d}$ represents $d$ and $q$ axis inductances, $V_{q}$ and $V_{d}$ represents $d$ and $q$ axis voltages, $\lambda$ induced flux amplitude, $R$ the stator windings resistance, $\omega_{m}$ is the angular velocity of the rotor, and $p$ is the number of pole pairs. The group of inverterdriven variable speed pumps may also be replaced, in principle and depending of the irrigation field design, by a single and larger pump. In this case, the capacity modulation would still be possible through wide variations of the pump speed, but such a design maybe limited by the availability of large rating components and by the low efficiency at reduced load

\section{System RATINGS AND CONTROL}

This system proposes a method for $100 \%$ capacity expansion of an irrigation farm pumping system. It is common to use multiple pumps in large farm irrigation pumping system for reachability, multiple access points to underground water, reliability and ease of maintenance. Also, a complex layout

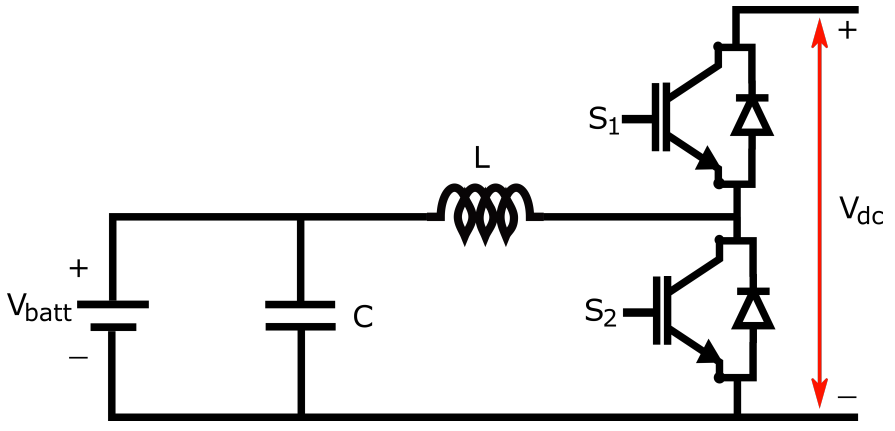

(a)

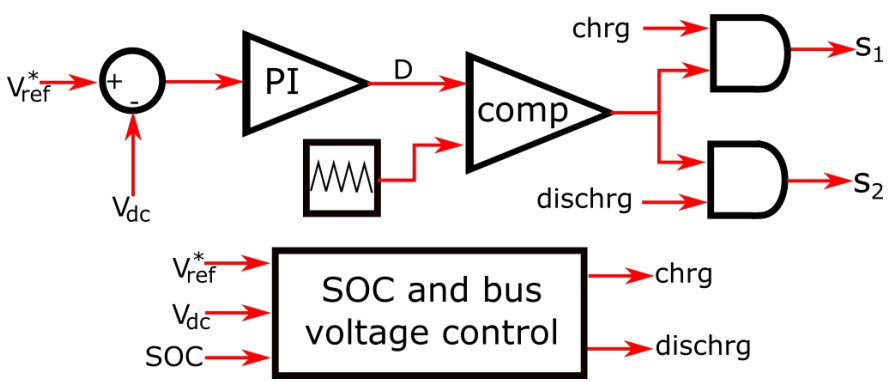

(b)

Fig. 3. (a) BESS connected to the dc bus through a DC-DC converter, where the switch $S_{1}$ is used in order to regulate the charging current and the switch $S_{2}$ controls the discharge current, (b) BESS converter control for allowing the battery to supply the current required in order to keep dc link voltage at the reference value.

is required in order to design a single high rated pump with a flat efficiency over all speeds. Multiple inverters are used to achieve independent control of each pumps using a rotor positioning device embedded in the PMSM. The connected pumps are rated for $0.25 \mathrm{MW}$ each with $0.69 \mathrm{kV}$ rated line to line voltage $\left(V_{L L}\right)$. The minimum dc link voltage $\left(V_{d c}\right)$ is calculated using,

$$
V_{d c}=\frac{3 \sqrt{2}}{\pi} V_{L L}=1.351 * 690 \mathrm{~V}=932.19 \mathrm{~V} .
$$

Thus, the system is designed with a dc link reference of $1 \mathrm{kV}$. An increase solar irradiance leads to higher output current of a PV module while increasing cell temperature decreases its output voltage. The maximum available power of a PV depends on its electrical properties and the atmospheric condition at the installation location while the operating point depends on the load connected to it. In order to ensure that the system PV array is constantly operating at its maximum power point (MPP), a buck converter is used to vary the magnitude of the impedance seen by the PV. In this design, the $\mathrm{PSCAD}^{T M} / \mathrm{EMTDC}^{T M}$ MPPT block, based on the incremental conductance method, is used to determine the voltage that corresponds to the MPP voltage $\left(V_{m p p t}\right)$ and a PI controller is used to regulate the duty cycle of the converter switch so that the PV output voltage is equal to $V_{m p p t}$.

The entire PV array is connected to the dc bus through a single buck converter and a uniform level of irradiance is assumed for all PV modules. More effective MPPT may be 


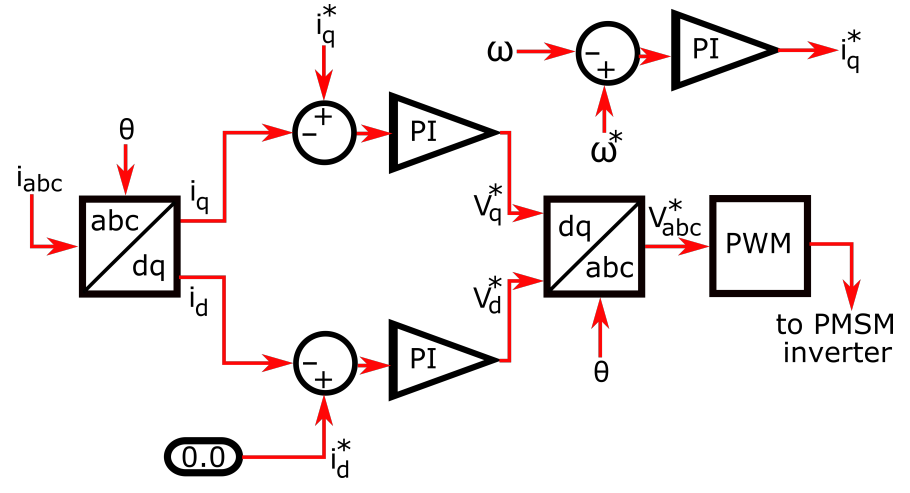

Fig. 4. Vector control of PMSM. The angle $\theta$ used in the transformations is derived from a rotor position encoder. The d-axis current is maintained as zero as required for maximum torque per ampere of surface mounted PMSMs.

achieved by dividing the PV array into multiple sections with individual DC-DC converter connected in parallel [20].

The battery bank is connected to the dc bus through a halfbridge bidirectional DC-DC converter, shown in Fig. 3a, which can either be operated as a boost converter to discharge the battery when the power from the solar system is insufficient and the battery SOC is above the minimum or operated as a buck converter to charge the battery when the power from is in excess of that required. Regulation of the DC bus voltage helps to achieve these control objectives, as a fluctuating value indicates power imbalance.

The BESS control circuit compares the dc link voltage $\left(V_{d c}\right)$ to the reference bus voltage $\left(V_{r e f}^{*}\right)$, and the difference is fed into a PI controller used to determine the duty cycle $(D)$ required to maintain $V_{d c}$ at reference value. The duty cycle is then compared with a high frequency triangular signal to provide corresponding switching pulses (Fig. 3b). The SOC and bus voltage control block is used to determine when the battery charges or discarge. If $V_{d c}$ is greater than $V_{r e f}^{*}$ while the battery is SOC is less than maximum, chrg is one, switch $S_{1}$ is enabled with the gating pulses and $S_{2}$ is zero. If $V_{d c}$ is less than $V_{r e f}^{*}$ while the battery is SOC is above the minimum, dischrg is one, switch $S_{2}$ is enabled with the gating pulses and $S_{1}$ is zero

The PMSM driven pumps are connected to the dc bus through a two level voltage source inverter (VSI) operating in speed control mode. The measured 3-phase pump currents $\left(i_{a b c}^{*}\right)$ are resolved along a rotor d-axis oriented reference frame using the rotor position $(\theta)$ for transformations. The component in phase with the permanent magnet flux, i.e. $i_{d}^{*}$ is maintained at zero to ensure maximum torque over all speed while the component in quadrature, $i_{q}^{*}$, is generated from an outer speed loop. Commanded and actual current components are compared to produce the corresponding modulating signal and in this study, sine-triangle PWM is used to produce the gating signals for the inverter switches (Fig. 4).

The grid connected bidirectional inverter supplies the pump load by regulation of the dc bus voltage when the battery is unavailable due to SOC constraints. The decoupled control of

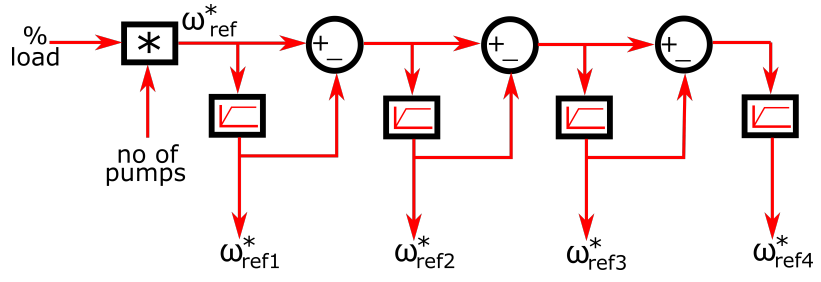

Fig. 5. Example implementation of capacity modulation control in which only the minimum number of pumps required to meet a given load are energized. The pumps may either be operated at full or partial load, depending on the load demand thereby allowing fine capacity modulation.

grid active and reactive power is achieved by the use of a reference frame oriented along the grid voltage. The position information required for the transformations is obtained by the use of a phase locked loop (PLL).

When the battery SOC is below the minimum and the dc link voltage is below the set value, the breaker is closed and the grid connected inverter draws the required real power from the grid to return the bus voltage to its reference. In case excess power is available from the PV system and the battery SOC is above its maximum, the dc bus voltage exceeds its set value and the grid draws the real power required to maintain the $\mathrm{dc}$ link voltage at the reference. The grid connected inverter can also be used to supply reactive power to the grid when the PV array is completely shaded and the connected pumps are not being operated.

The amount of water required in large irrigation farms varies with season of the year where summer sees the maximum water demand. Just like compressor modulation for air conditioning system, the number of energized pumps in an irrigation system can be modulated such that only the minimum amount of pumps required to meet a specified load demand are used (Fig. 5). Other implementations are possible, for example, with the all the pumps operated at the same reduced speed below rated value, or in another instance, the speeds for the pumps can be different with one typical situation being with three pumps operating at rated speed for full power and one at reduced speed. It is recommended to alternate the sequence of pump operations so that one pump is not operated more than the others and maintenance date is the same for all pumps.

\section{Simulation Results}

To validate the effectiveness of the proposed system and controls, the system described in Fig. 1 was modeled in PSCAD and comprehensive analyses for three cases were made. The simulations include the demonstration of capacity modulation and operation and response of the system under sudden shading of the solar PV. The last simulated case is on control of the battery considering its state of charge, very important for extending the lifetime of the battery.

Case I: To demonstrate the proposed capacity modulation technique, the pumping system was operated at different loads. The system is initially operating at $15 \%$ load requirement corresponding to the speed of $0.6 \mathrm{pu}$. The load demand is increased to $25 \%, 50 \%, 75 \%$ and $100 \%$ of the rated condition 


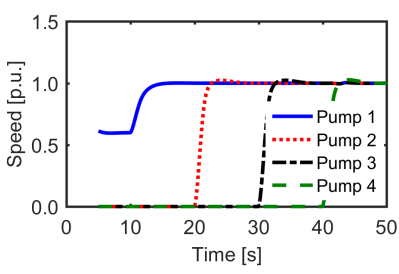

(a)

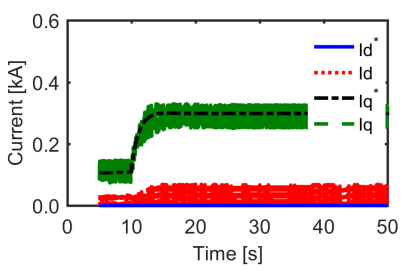

(c)

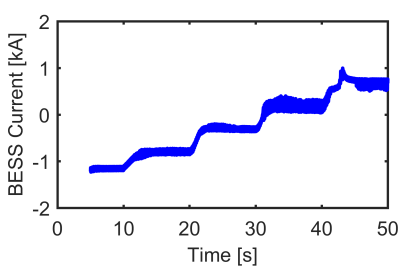

(e)

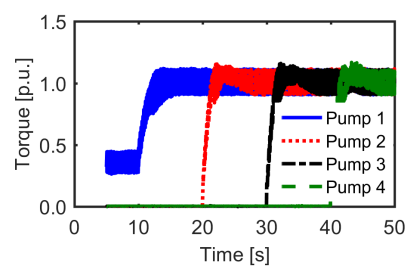

(b)

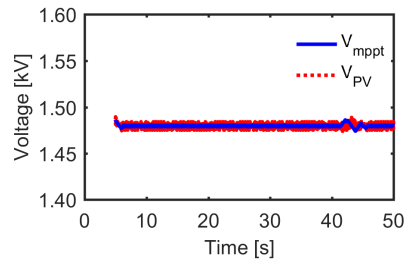

(d)

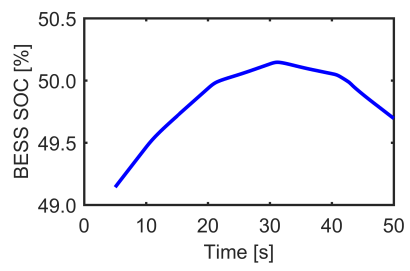

(f)
Fig. 6. Case study I: multiple pumps are used to achieve incremental capacity modulation up to maximum available power for $700 \mathrm{~W} / \mathrm{m}^{2}$. (a) Speed of the pump motors,(b) torque of the pump motors,(c) motor reference and actual $\mathrm{d}$ and $\mathrm{q}$ axes currents (d) MPPT reference and array voltage, (e) battery current, and (f) battery SOC.

at 10 s intervals. With every step increase after $25 \%$, additional pumps are energized to meet the specified load requirements till all pumps are operational at 100\% load requirement (Fig. $6 a$ and $b$ ).

The PMSMs operating the pumps are vector controlled and operating with the d-axis current at zero (Fig. 6c). At all operating conditions, the solar PV system operates at its maximum power point (Fig. 6d). At 30s of time, the battery, which was initially charging to maintain the PV system power at its MPP as well as the power balance, changes its mode to discharging in order to supply the power required by the pumps while regulating the dc bus voltage at $1 \mathrm{kV}$ (Fig. 6e and f).

Case II: With the pumps being operated at $75 \%$ load requirements throughout this entire case, the PV system with an initial solar irradiance of $1000 \mathrm{~W} / \mathrm{m}^{2}$ was suddenly shaded such that it reduced to $500 \mathrm{~W} / \mathrm{m}^{2}$ (Fig 7a). The PV system controller outputs a voltage corresponding to the new MPP and the buck converter adjusts its duty cycle so that the array terminal voltage corresponds to the new reference voltage (Fig $7 b)$.

The BESS supplies the power deficit and switches from charging to discharging mode until the PV system returns to its initial irradiance level then the BESS charges from the dc bus so that it does not increase above its reference due to

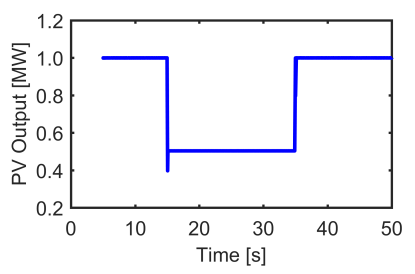

(a)

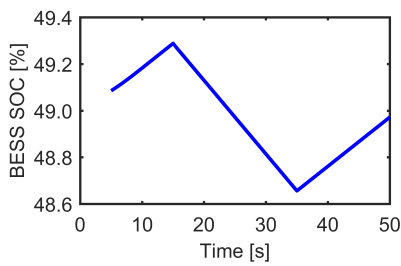

(c)

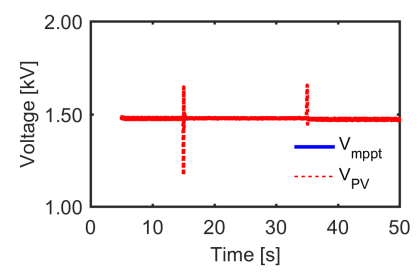

(b)

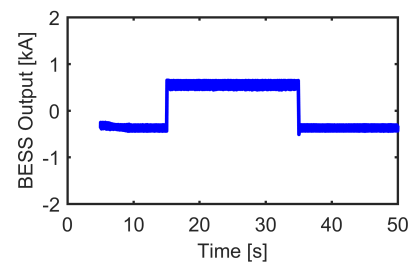

(d)
Fig. 7. Case study II: The PV array is suddenly shaded, and this incident lasts for 20s, from 15s-35s. Battery switches from charging to discharge mode during this period, and supplies power. It returns to the charging mode when the power from the PV becomes available once again. (a) PV output power, (b) MPPT reference and array voltage, (c) battery SOC, and (d) battery output current.

excess power from the PV array (Fig 7c and d).

Case III: The PV array, initially operating at $1000 \mathrm{~W} / \mathrm{m}^{2}$ is suddenly shaded to $500 \mathrm{~W} / \mathrm{m}^{2}$ at $15 \mathrm{~s}$ of time. As per the control algorithm, the BESS is used to supply the power deficit. However, to ensure longer battery lifetime, when SOC is below the minimum, taken in this study as $20 \%$, the battery is prevented from discharging.

At about $25 \mathrm{~s}$ of time, the BESS SOC reaches its minimum (Fig. 8 a) and the controller of the grid side inverter senses this change, from fluctuations in the dc bus voltage (Fig. 8 b) and supplies the amount of power needed to maintain the pumps at the required speeds (Fig. $8 \mathrm{c}$ ). At this time, the battery is idle (Fig. 8 d).

\section{CONCLUSION}

The paper presents a solution for increasing the capacity of an irrigation farm through the combined use of PV generation, battery storage, and capacity modulation using variable speed permanent magnet synchronous motor drives for the newly added pumps. The new approach presents multiple advantages, as it reduces the energy demand on a rural power grid, enables the integration of clean renewable energy, with much of the installation operating on a PV supply during the day, and enhances the stability and reliability of the power system. In this respect, specific algorithms for the battery management system and the grid side inverter have been developed in order to allow the independent control of active and reactive power.

Substantial energy savings are achieved through capacity modulation of the pumps. Combinations of line-fed and power electronic inverter-fed pumps are employed with some of the later operating at reduced speed and resulting, according to the pump affinity law, to reduced energy consumption for the same 


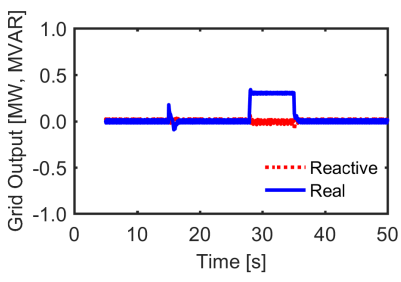

(a)

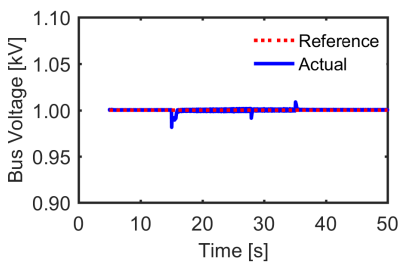

(c)

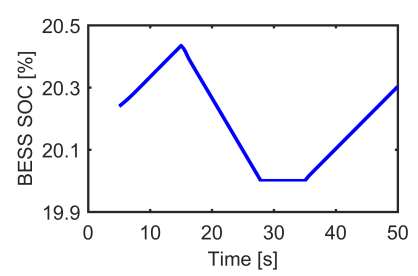

(b)

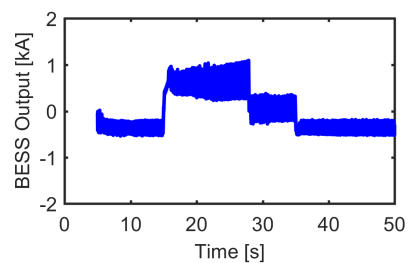

(d)
Fig. 8. Case study III: PV array is suddenly shaded for 20 s simulation time The battery supplies the remaining power to the pumps till it reaches the minimum state of charge, upon the occurrence of which, the grid supplies this power instead. (a) Battery SOC, (b) dc bus reference and actual voltage, (c) grid output power, and (d) battery output current.

amount of circulated liquid. In the recommended approach described in the paper, each of the variable speed pumps employs its own inverter allowing for capacity modulation in small increments of power and taking into account the specifics of the installation field layout. The detailed technical advantages of the system, in terms of modulation, integrated PV and battery optimal operation, and mitigation of transient effects during solar shading, were illustrated through PSCAD $^{T M} /$ EMTDC $^{T M}$ simulations on three case studies. System design variations and quantification of potential additional benefits, such as sizing and using the battery for microgrid islanded operation, weak grid support and frequency regulation, are the object of on-going research.

\section{REFERENCES}

[1] M. A. G. de Brito, L. Galotto, L. P. Sampaio, G. d. A. e Melo, and C. A. Canesin, "Evaluation of the main mppt techniques for photovoltaic applications," IEEE Transactions on Industrial Electronics, vol. 60, no. 3, pp. 1156-1167, March 2013.

[2] B. Xiao, L. Hang, J. Mei, C. Riley, L. M. Tolbert, and B. Ozpineci, "Modular cascaded h-bridge multilevel pv inverter with distributed mppt for grid-connected applications," IEEE Transactions on Industry Applications, vol. 51, no. 2, pp. 1722 1731, March 2015.

[3] M. Killi and S. Samanta, "Modified perturb and observe mppt algorithm for drift avoidance in photovoltaic systems," IEEE Transactions on Industrial Electronics, vol. 62, no. 9, pp. 55495559, Sept 2015.

[4] T. Koyasu, K. Yukita, K. Ichiyanagi, M. Minowa, M. Yoda, and $\mathrm{K}$. Hirose, "Forecasting variation of solar radiation and movement of cloud by sky image data," in 2016 IEEE International Conference on Renewable Energy Research and Applications (ICRERA), Nov 2016, pp. 401-406.

[5] M. T. Ahmed, T. Gonalves, and M. Tlemcani, "Single diode model parameters analysis of photovoltaic cell," in 2016 IEEE International Conference on Renewable Energy Research and Applications (ICRERA), Nov 2016, pp. 396-400.
[6] I. G. Adebayo, A. A. Jimoh, and A. A. Yusuff, "Identification of suitable nodes for the placement of reactive power compensators," in 2016 IEEE International Conference on Renewable Energy Research and Applications (ICRERA), Nov 2016, pp. 645-649.

[7] C. Verdugo, J. I. Candela, and P. Rodriguez, "Grid support functionalities based on modular multilevel converters with synchronous power control," in 2016 IEEE International Conference on Renewable Energy Research and Applications (ICRERA), Nov 2016, pp. 572-577.

[8] H. P. H. Anh and N. H. Phuc, "Implementation an adaptive fuzzy narx controller for mppt pv supplied dc pump motor," in 2012 10th International Power Energy Conference (IPEC), Dec 2012, pp. 550-555.

[9] A. Bhattacharjee, D. K. Mandal, and H. Saha, "Design of an optimized battery energy storage enabled solar pv pump for rural irrigation," in 2016 IEEE 1st International Conference on Power Electronics, Intelligent Control and Energy Systems (ICPEICES), July 2016, pp. 1-6.

[10] W. Wareesri and S. Po-Ngam, "A three-phase pv-pump inverter with maximum power point tracking (mppt) controller," in 2016 13th International Conference on Electrical Engineering/Electronics, Computer, Telecommunications and Information Technology (ECTI-CON), June 2016, pp. 1-4.

[11] E. Hayakwong, V. Kinnares, and C. Bunlaksananusorn, "Twophase induction motor drive improvement for $\mathrm{pv}$ water pumping system," in 2016 19th International Conference on Electrical Machines and Systems (ICEMS), Nov 2016, pp. 1-6.

[12] R. Kumar and B. Singh, "Solar pv powered bldc motor drive for water pumping using cuk converter," IET Electric Power Applications, vol. 11, no. 2, pp. 222-232, 2017.

[13] I. S.-B. E. M. marwa ben said, Wissem Naouar, "Indirect sliding mode power control associated to virtual resistor based active damping method for llcl-filter-based grid-connected converters," International Journal of Renewable Energy Research-IJRER, vol. 7, no. 3, Sept 2017.

[14] U. S. Swaminathan Ganesan, Ramesh V, "Hybrid control of microgrid with pv, diesel generator and bess," International Journal of Renewable Energy Research-IJRER, vol. 7, no. 3, Sept 2017.

[15] A. N. Dr. Jayalakshmi N. S., Dr. D. N. Gaonkar, "Design and analysis of dual output flyback converter for standalone pv/battery system," International Journal of Renewable Energy Research-IJRER, vol. 7, no. 3, Sept 2017.

[16] S. P. S. P. V.K. Arun Shankar, S. Umashankar, "Adaptive neurofuzzy inference system ( anfis ) based direct torque control of pmsm driven centrifugal pump," International Journal of Renewable Energy Research-IJRER, vol. 7, no. 3, Sept 2017.

[17] H. Othmani, "Adaptive neuro-fuzzy inference system ( anfis ) based direct torque control of pmsm driven centrifugal pump," International Journal of Renewable Energy Research-IJRER, vol. 7, no. 3, Sept 2017.

[18] S. A. Hamidi, D. M. Ionel, and A. Nasiri, "Batteries and ultracapacitors for electric power systems with renewable energy sources," Renewable Energy Devices and Systems with Simulations in MATLAB® and ANSYS $R, 2017$.

[19] M. Chen and G. A. Rincon-Mora, "Accurate electrical battery model capable of predicting runtime and iv performance," IEEE transactions on energy conversion, vol. 21, no. 2, pp. 504-511, 2006.

[20] V. Rallabandi, O. M. Akeyo, and D. M. Ionel, "Modeling of a multi-megawatt grid connected pv system with integrated batteries," in 2016 IEEE International Conference on Renewable Energy Research and Applications (ICRERA), Nov 2016, pp. 1146-1151. 